\title{
'Immunogenetics of Aging': report on the activities of the 15th International HLA and Immunogenetics Working Group and 15th International HLA and Immunogenetics Workshop
}

\author{
E. Naumova ${ }^{1}$, M. Ivanova ${ }^{1}$, G. Pawelec ${ }^{2}$, I. Constantinescu ${ }^{3}$, K. Bogunia-Kubik ${ }^{4}$, A. Lange ${ }^{4}$, F. Qguz ${ }^{5}$, \\ M. Carin ${ }^{5}$, C. Franceschi ${ }^{6}$, C. Caruso ${ }^{7}$ \& D. Middleton ${ }^{8}$ \\ 1 Department of Clinical Immunology, University Hospital Alexandrovska, Sofia, Bulgaria \\ 2 Center for Medical Research, University of Tübingen, Tübingen, Germany \\ 3 Fundeni Clinical Institute Centre for Immunogenetics and Virology, Bucharest, Romania \\ 4 Department of Clinical Immunology, Ludwik Hirzfeld Institute of Immunology and Experimental Therapy, Wroclaw, Poland \\ 5 Department of Medical Biology, Istanbul Medical Faculty, Istanbul University, Istanbul, Turkey \\ 6 Department of Experimental Pathology, University of Bologna, Bologna, Italy \\ 7 Dipartimento di Biopatologia e Metodologie Biomediche, Università di Palermo, Palermo, Italy \\ 8 Transplant Immunology, Royal Liverpool University Hospital, Liverpool, UK
}

\section{Key words}

aging; cytokine gene polymorphism; killer-cell immunoglobulin-like receptor genes; longevity; mannose-binding lectin 2 gene

\author{
Correspondence \\ E. Naumova \\ Department of Clinical Immunology \\ University Hospital Alexandrovska \\ 1.G. Sofiisky Street \\ 1431 Sofia \\ Bulgaria \\ Tel: +35929230690 \\ Fax: +35929230 496 \\ e-mail: immunology@abv.bg
}

Received 23 September 2009; revised 20 October 2010; accepted 1 November 2010 doi: 10.1111/j.1399-0039.2010.01603.x

\begin{abstract}
'Immunogenetics of Aging' is a component that was first included in the 14th International HLA and Immunogenetics Workshop (IHIWS) and developed further within the 15th Workshop. The aim of this component was to assess the impact of human leukocyte antigen (HLA) genes, cytokine genes, and some innate immunity genes such as killer-cell immunoglobulin-like receptors (KIRs) and mannose-binding lectin 2 (MBL2) in successful aging and their contribution to the better understanding of immune dysfunction in old age. Within the 15th IHIWS new populations were included in the analysis. Additional cytokine gene polymorphisms were assessed and innate immunity genes were analyzed for possible relevance in longevity. The results showed that longevity might be associated with anti-inflammatory cytokine gene profiles, decreased frequency of interleukin-10 (IL-10) and transforming growth factor-B1 haplotypes associated with a low level of gene expression, and increased frequency of haplotypes determining a high level of expression. Extended tumor necrosis factor-A and IL-12B genotypes were also likely relevant to longevity. Data also showed that innate immunity genes are associated with susceptibility to infections in the elderly and showed that these genes might be an important genetic marker in aging. Decreased frequencies of KIR2DS5 and A1B10 haplotypes, and an increased proportion of MBL2-deficient haplotypes were found in the group with higher cytomegalovirus-specific IgG antibody levels. Together, these studies emphasize the relevance of genes regulating immune functions in maintaining human longevity and stress the importance of further clarifying their impact on successful aging.
\end{abstract}

The aging process is very complex and longevity is a multifactorial trait, which is determined by genetic and environmental factors and the interaction of 'disease' processes with 'intrinsic' aging processes. Twin studies show that genes account for $15-30 \%$ of human lifespan determination $(1,2)$. Many studies showed that there are genetic differences between centenarians and the general population. Additionally, family studies showed that the siblings of centenarians have a higher likelihood of reaching old age than the general population (3). It is hypothesized that the level of immune response influences longevity, and that this should therefore be associated with genes regulating immune functions (4). The 'Immunogenetics of Aging' program is a component included within the 14th International HLA and Immunogenetics Workshop (IHIWS) developed further within the 15th. The aim of this component was to determine the contribution of immune genes to successful aging and an increased capacity to reach the extreme limits of lifespan. Two main 
data sets were collected: families with long-lived members (octogenarians and nonagenarians) and unrelated elderly individuals compared with ethnically matched young controls. As part of 14th IHIWS, the effect of classical human leukocyte antigen (HLA) class I and class II loci and cytokine polymorphisms in regulatory and/or coding regions, with a possible impact on the level of gene expression of pro- and anti-inflammatory cytokines, was analyzed. Results showed that longevity in the populations studied is positively associated with $\mathrm{DRB} 1 * 11$ - and DRB1*16-associated haplotypes and with increased anti-inflammatory cytokine genotypes (5). During the 15th IHIWS, the number of samples collected was increased, polymorphisms in cytokine genes and innate immunity genes such as killer-cell immunoglobulin-like receptor (KIR) and MBL2 were included in the analysis. Linkage and association analyses were performed in order to identify extended immunogenetic profiles that could be relevant to a better understanding of the mechanisms contributing to successful aging and longevity.

Several previous studies had showed that cytokine dysregulation is associated with different disorders including agerelated disease. Increased interleukin-6 (IL-6) levels in the elderly (6) are associated with the development of frailty and susceptibility to diseases (7). Additionally, several investigators reported increased ex vivo capacity of macrophages from the elderly to produce IL-10 and increased transforming growth factor- $\beta$ (TGF- $\beta$ ) levels (6). On the other hand, decreased capacity to produce interferon- $\gamma$ (IFN- $\gamma$ ) was observed in cells from the elderly upon stimulation. Studies over the last few years have shown that polymorphisms in the regulatory regions of cytokine genes could affect gene transcription and cause different cytokine production levels (8). Although some investigators have shown associations of cytokine gene polymorphism with longevity, data are still controversial and inconclusive (9-16).

This report will review the analyses of data collected by the Immunogenetics of Aging Working Group. Results on cytokine gene polymorphisms and innate immunity genes in unrelated elderly and controls and families with long-lived members are presented. Finally, the report will summarize the future plans of the Immunogenetics of Aging Working Group.

Two main data sets were included in this study: unrelated healthy elderly individuals and ethnically matched young controls, and families with long-lived members. The following selection criteria were used to identify families for the study: extended families with a family history of at least two generations with long-lived members (octogenarians and nonagenarians) including elderly individuals, their children, and grandchildren; availability of sufficient demographic data; and data on family history of diseases. Elderly individuals (in family-based analyses and unrelated case-control analyses) were characterized according to the SENIEUR protocol (17). The unrelated young controls were characterized according to JUNIEUR protocol (17).
Table 1 Number of elderly and young individuals from each population and testing performed within the component Immunogenetics of Aging

\begin{tabular}{|c|c|c|c|c|}
\hline \multirow[b]{2}{*}{ Population } & \multicolumn{3}{|c|}{ Number of individuals } & \multirow{2}{*}{$\begin{array}{c}\text { Genetic markers } \\
\text { analyzed }\end{array}$} \\
\hline & Elderly & Young & Families & \\
\hline Bulgarians & 60 & 100 & $\begin{array}{c}12 \text { families (three } \\
\text { generations) }\end{array}$ & $\begin{array}{l}\text { HLA }^{a}, \text { IL-2, IL-6, } \\
\text { IL-10, TNF-A, } \\
\text { TGF-B1, IFN- } \gamma, \\
\text { IL-12B, KIR, MBL2 }\end{array}$ \\
\hline Turkish & 237 & 90 & & $\begin{array}{l}\text { HLA }^{a}, \text { TNF-A, } \\
\text { TGF-B1, IL-10, IL-6, } \\
\text { IFN- } \gamma\end{array}$ \\
\hline Romanians & 32 & 44 & & $\mathrm{HLA}^{a}$ \\
\hline Polish & & 129 & & $\begin{array}{l}\text { HLA }^{a}, \text { TNF-A, IL-6, } \\
\text { IFN- } \gamma, \text { IL-10 }\end{array}$ \\
\hline Italians & 410 & 20 & & $\begin{array}{c}\text { IL-10, IFN- } \gamma, \text { TNF-A, } \\
\text { IL-2, IL-12B, KIR }\end{array}$ \\
\hline Irish & 100 & 100 & & KIR \\
\hline
\end{tabular}

HLA, human leukocyte antigen; IFN- $\gamma$, interferon- $\gamma$; IL, interleukin; KIR, killer-cell immunoglobulin-like receptor; MBL2, mannose-binding lectin 2; TGF-B1, transforming growth factor-B1; TNF-A, tumor necrosis factor-A. a HLA analysis was performed within the 14th IHIWS.

Data on six populations (the Bulgarian, Romanian, Polish, Turkish, Italian, and Irish) are included in the component Immunogenetics of Aging. During the 15th IHIWS, an additional 572 healthy randomly selected elderly individuals (aged 65-99) were collected. A total of 602 elderly, 393 young controls, and 12 families with long-lived members, including 17 unrelated elderly (65-90 years) and 23 family members (18-57 years) were analyzed within this component. The number of elderly and young individuals from each population and the testing performed are given in Table 1.

In addition to the genetic markers HLA-A, -B, -DRB1, -DQB1 loci, and single nucleotide polymorphisms (SNPs) in cytokine genes possibly associated with the level of gene expression [tumor necrosis factor-A (TNF-A); TGF-B1; IL10; IL-6; IFN- $\gamma$, IL-2] analyzed as a part of the 14th IHIWS (5), extended genotypes in TNF-A, IL-12B, and TGF$\mathrm{B} 1$ genes were assessed and new genetic markers (MBL2 and KIR) were included within the 15 th IHIWS.

The additional single nucleotide gene polymorphisms in cytokine genes TNF-A, TGF-B1, and IL-12B were assessed by polymerase chain reaction-sequencing based typing (PCR-SBT) methods. KIR genotyping was performed by PCR sequence-specific oligonucleotide (PCR-SSO) and PCR sequence-specific primers (PCR-SSP) methods. For the analysis of MBL2 haplotypes, including six SNPs associated with the protein level, a Luminex-based method was applied (18).

Allele frequencies were estimated by maximum-likelihood analysis using the Arlequin program v1.1 (19). Standard deviations were calculated from 100 bootstrap iterations. Hardy-Weinberg equilibrium was tested by a hidden Markov chain with 100,000 steps, implemented in the Arlequin program. Arlequin software was also used to estimate 
maximum-likelihood three-locus haplotype frequencies from genotypic data through an expectation-maximization (EM) algorithm (20). Haplotypes were confirmed by inheritance in families. Comparisons across different age groups were assessed by the chi-squared test or Fischer exact test when appropriate. A $P$-value lower than 0.05 was considered to indicate a significant difference between groups. Bonferroni correction for multiple comparisons was applied.

In this report we detail the major findings of the collaborative study within the 15 th IHIWS. Analysis of cytokine gene polymorphisms in this study showed no statistically significant differences between the elderly individuals and the control groups from different populations for genotype frequencies of the generally pro-inflammatory cytokines IL-2, IL-6, and IFN- $\gamma$. However, associations with longevity were observed for IL-10 haplotypes (Table 2), which were determined by EM algorithm which had been validated in 12 families. The IL-10 haplotype (-1082G, $-819 \mathrm{C}$, and $-592 \mathrm{C})$ associated with high-level cytokine gene expression was significantly more prevalent among healthy elderly to young controls $\left(P_{\mathrm{c}}<\right.$ 0.05). These results were observed in both the Bulgarian and the Turkish populations. Additionally, in Bulgarians the IL-10 haplotype $(-1082 \mathrm{~A},-819 \mathrm{~T}$, and $-592 \mathrm{~A})$, possibly related to a lower level of gene expression, was found with slightly lower frequency in the elderly. In the Turkish population, a decreased frequency of another low-level IL-10 haplotype $(-1082 \mathrm{~A},-819 \mathrm{C}$, and $-592 \mathrm{C})$ was observed in the elderly $\left(P_{\mathrm{c}}<0.05\right)$. The observations imply that longevity might be associated with anti-inflammatory cytokine gene profiles.

Analysis of the extended TNF-A genotypes showed significant differences between elderly individuals and young controls. A genotype, possibly related to low-level expression, was more frequent among healthy elderly Bulgarians compared with young controls (Table 3).

Analysis of genotypes of anti-inflammatory TGF-B1 also showed possible association with aging. The genotype TGF-B1 (codon 10) T/T; (codon 25) G/G, related to high levels of gene expression, was increased in elderly compared with young controls $(P<0.05)$. In contrast there was a trend to a lower frequency in elderly of the genotype TGF-B1 (codon 10) $\mathrm{C} / \mathrm{C}$; (codon 25 ) $\mathrm{G} / \mathrm{G}$, associated with low protein level (Table 4). Analysis of extended TGF-B1 genotypes in

Table 2 IL-10 haplotypes in elderly and young controls

\begin{tabular}{|c|c|c|c|c|}
\hline \multirow[b]{3}{*}{$\begin{array}{l}\text { IL-10 (-1082; -819; } \\
\text {-592) haplotypes }\end{array}$} & \multicolumn{4}{|c|}{ Haplotype frequency } \\
\hline & \multicolumn{2}{|c|}{ Bulgarians } & \multicolumn{2}{|c|}{ Turkish } \\
\hline & $\begin{array}{l}\text { Elderly } \\
(n=60)\end{array}$ & $\begin{array}{l}\text { Young } \\
(n=60)\end{array}$ & $\begin{array}{c}\text { Elderly } \\
(n=237)\end{array}$ & $\begin{array}{l}\text { Young } \\
(n=90)\end{array}$ \\
\hline ACC (low) & 0.297 & 0.336 & $0.261^{* *}$ & $0.364^{* *}$ \\
\hline ATA (low) & $0.238^{*}$ & $0.358^{*}$ & 0.291 & 0.250 \\
\hline GCC (high) & $0.466^{* *}$ & $0.306^{* *}$ & $0.487^{* *}$ & $0.386^{* *}$ \\
\hline
\end{tabular}

$\mathrm{IL}$, interleukin.

${ }^{*} P<0.05, P_{\mathrm{c}}=\mathrm{ns} ;{ }^{* *} P<0.01, P_{\mathrm{c}}<0.05$.
Table 3 Extended TNF-A genotypes in elderly Bulgarians compared with ethnically matched controls

\begin{tabular}{|c|c|c|c|c|c|c|}
\hline \multicolumn{5}{|c|}{ TFN-A genotypes } & \multicolumn{2}{|c|}{ Genotype frequency } \\
\hline-1031 & -863 & -857 & -308 & +489 & $\begin{array}{c}\text { Elderly } \\
(n=60)\end{array}$ & $\begin{array}{l}\text { Young } \\
(n=50)\end{array}$ \\
\hline $\mathrm{C} / \mathrm{C}$ & $A / A$ & $\mathrm{C} / \mathrm{C}$ & $\mathrm{G} / \mathrm{G}$ & $\mathrm{G} / \mathrm{G}$ & 0.028 & 0.040 \\
\hline $\mathrm{C} / \mathrm{C}$ & C/A & $\mathrm{C} / \mathrm{C}$ & $\mathrm{G} / \mathrm{G}$ & G/G** (low) & 0.083 & 0.000 \\
\hline $\mathrm{C} / \mathrm{C}$ & $\mathrm{C} / \mathrm{C}$ & $\mathrm{C} / \mathrm{C}$ & $\mathrm{G} / \mathrm{G}$ & $\mathrm{G} / \mathrm{G}$ & 0.056 & 0.000 \\
\hline $\mathrm{C} / \mathrm{C}$ & $\mathrm{C} / \mathrm{C}$ & $\mathrm{C} / \mathrm{T}$ & $\mathrm{G} / \mathrm{G}$ & $\mathrm{G} / \mathrm{A}$ & 0.028 & 0.040 \\
\hline $\mathrm{T} / \mathrm{C}$ & A/A & $\mathrm{C} / \mathrm{T}$ & $\mathrm{G} / \mathrm{G}$ & $\mathrm{G} / \mathrm{A}$ & 0.028 & 0.000 \\
\hline $\mathrm{T} / \mathrm{C}$ & C/A & $\mathrm{C} / \mathrm{C}$ & $\mathrm{G} / \mathrm{A}$ & $\mathrm{G} / \mathrm{G}$ & 0.056 & 0.000 \\
\hline $\mathrm{T} / \mathrm{C}$ & C/A & $\mathrm{C} / \mathrm{C}$ & $\mathrm{G} / \mathrm{G}$ & G/G* (low) & 0.167 & 0.040 \\
\hline $\mathrm{T} / \mathrm{C}$ & C/A & $\mathrm{C} / \mathrm{T}$ & $\mathrm{G} / \mathrm{G}$ & $\mathrm{G} / \mathrm{A}$ & 0.028 & 0.000 \\
\hline $\mathrm{T} / \mathrm{C}$ & $\mathrm{C} / \mathrm{C}$ & $\mathrm{C} / \mathrm{C}$ & $\mathrm{G} / \mathrm{G}$ & $\mathrm{G} / \mathrm{G}$ & 0.028 & 0.080 \\
\hline $\mathrm{T} / \mathrm{C}$ & $\mathrm{C} / \mathrm{C}$ & $\mathrm{C} / \mathrm{C}$ & $\mathrm{G} / \mathrm{A}$ & $\mathrm{G} / \mathrm{G}$ & 0.000 & 0.040 \\
\hline $\mathrm{T} / \mathrm{T}$ & $\mathrm{C} / \mathrm{C}$ & $\mathrm{C} / \mathrm{C}$ & $\mathrm{A} / \mathrm{A}$ & $\mathrm{G} / \mathrm{G}$ & 0.028 & 0.040 \\
\hline $\mathrm{T} / \mathrm{T}$ & $\mathrm{C} / \mathrm{C}$ & $\mathrm{C} / \mathrm{C}$ & $\mathrm{G} / \mathrm{A}$ & $\mathrm{G} / \mathrm{A}$ & 0.028 & 0.000 \\
\hline $\mathrm{T} / \mathrm{T}$ & $\mathrm{C} / \mathrm{C}$ & $\mathrm{C} / \mathrm{C}$ & G/A & $\mathrm{G} / \mathrm{G}$ & 0.111 & 0.080 \\
\hline $\mathrm{T} / \mathrm{T}$ & $\mathrm{C} / \mathrm{C}$ & $\mathrm{C} / \mathrm{C}$ & $\mathrm{G} / \mathrm{G}$ & $\mathrm{G} / \mathrm{G}$ & 0.083 & 0.200 \\
\hline $\mathrm{T} / \mathrm{T}$ & $\mathrm{C} / \mathrm{C}$ & $\mathrm{C} / \mathrm{T}$ & $\mathrm{G} / \mathrm{A}$ & $\mathrm{G} / \mathrm{A}$ & 0.056 & 0.080 \\
\hline $\mathrm{T} / \mathrm{T}$ & $\mathrm{C} / \mathrm{C}$ & $\mathrm{C} / \mathrm{T}$ & $\mathrm{G} / \mathrm{G}$ & $\mathrm{G} / \mathrm{A}$ & 0.111 & 0.120 \\
\hline $\mathrm{T} / \mathrm{T}$ & $\mathrm{C} / \mathrm{C}$ & $\mathrm{C} / \mathrm{T}$ & $\mathrm{G} / \mathrm{G}$ & $\mathrm{G} / \mathrm{G}$ & 0.028 & 0.000 \\
\hline $\mathrm{T} / \mathrm{T}$ & $\mathrm{C} / \mathrm{C}$ & $\mathrm{T} / \mathrm{T}$ & $\mathrm{G} / \mathrm{G}$ & $\mathrm{A} / \mathrm{A}$ & 0.056 & 0.120 \\
\hline
\end{tabular}

TNF-A, tumor necrosis factor-A.

${ }^{*} P<0.05, P_{\mathrm{c}}=\mathrm{ns} ;{ }^{* *} P<0.01, P_{\mathrm{c}}<0.05$.

Table 4 TGF-B1 genotypes in elderly compared with young controls

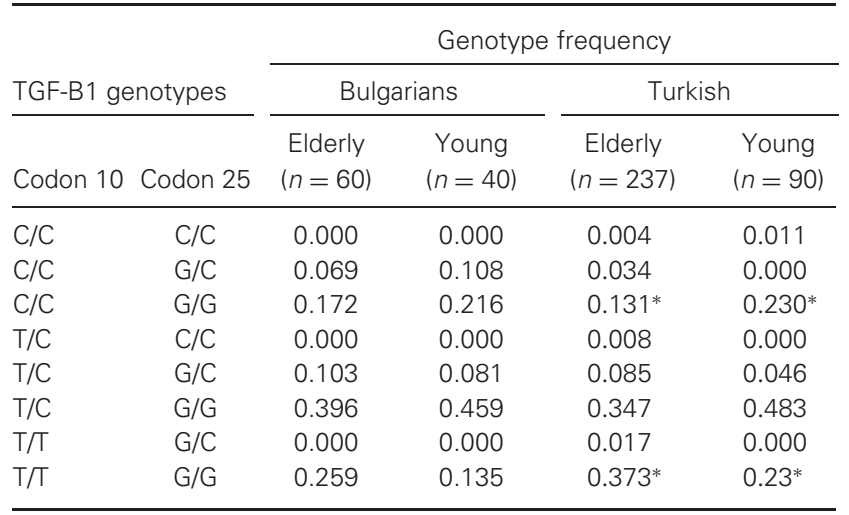

TGF-B1, transforming growth factor-B1.

$* P<0.05, P_{\mathrm{C}}=\mathrm{ns}$.

Bulgarians showed that genotype TGF-B1 (codon 10) $\mathrm{C} / \mathrm{C}$; (codon 25) G/G; (-988) C/C; (-800) G/G was decreased, while the genotype TGF-B1 (codon 10) T/C; (codon 25) $\mathrm{G} / \mathrm{G}$; (-988) C/C; (-800) G/A was increased in elderly compared with the controls (Table 5). Based on codon 10 and 25 these genotypes are associated with low- and high-level gene expression, respectively. As the positions -988 and -800 are located in the promoter region of the gene they could also possibly modulate the expression of TGF-B1.

Analysis of IL-12B extended genotypes did not show any statistically significant associations despite of the slightly increased frequencies of (1188) C/C; (2124) A/A genotype in elderly compared with young controls in both Bulgarians and 
Table 5 Extended TGF-B1 genotypes in elderly Bulgarians compared with ethnically matched controls

\begin{tabular}{|c|c|c|c|c|c|}
\hline \multicolumn{4}{|c|}{ TGF-B1 genotypes } & \multicolumn{2}{|c|}{ Genotype frequency } \\
\hline Codon 10 & Codon 25 & -988 & -800 & $\begin{array}{l}\text { Elderly } \\
(n=60)\end{array}$ & $\begin{array}{l}\text { Young } \\
(n=40)\end{array}$ \\
\hline $\mathrm{C} / \mathrm{C}$ & $\mathrm{G} / \mathrm{C}$ & $\mathrm{C} / \mathrm{C}$ & $\mathrm{G} / \mathrm{G}$ & 0.034 & 0.056 \\
\hline $\mathrm{C} / \mathrm{C}$ & $\mathrm{G} / \mathrm{C}$ & $\mathrm{C} / \mathrm{T}$ & $\mathrm{G} / \mathrm{G}$ & 0.034 & 0.000 \\
\hline $\mathrm{C} / \mathrm{C}$ & $\mathrm{G} / \mathrm{G}$ & $\mathrm{C} / \mathrm{C}$ & $\mathrm{G} / \mathrm{G}^{*}(\mathrm{low})$ & 0.085 & 0.254 \\
\hline $\mathrm{C} / \mathrm{C}$ & G/G & $\mathrm{C} / \mathrm{T}$ & $\mathrm{G} / \mathrm{G}$ & 0.034 & 0.000 \\
\hline $\mathrm{T} / \mathrm{C}$ & $\mathrm{G} / \mathrm{C}$ & $\mathrm{C} / \mathrm{C}$ & $\mathrm{G} / \mathrm{A}$ & 0.017 & 0.028 \\
\hline $\mathrm{T} / \mathrm{C}$ & $\mathrm{G} / \mathrm{C}$ & $\mathrm{C} / \mathrm{C}$ & G/G & 0.068 & 0.056 \\
\hline $\mathrm{T} / \mathrm{C}$ & $\mathrm{G} / \mathrm{G}$ & $\mathrm{C} / \mathrm{C}$ & G/A* (high) & 0.051 & 0.000 \\
\hline $\mathrm{T} / \mathrm{C}$ & G/G & $\mathrm{C} / \mathrm{C}$ & $\mathrm{G} / \mathrm{G}$ & 0.272 & 0.306 \\
\hline $\mathrm{T} / \mathrm{C}$ & $\mathrm{G} / \mathrm{G}$ & $\mathrm{C} / \mathrm{T}$ & $\mathrm{G} / \mathrm{G}$ & 0.034 & 0.028 \\
\hline $\mathrm{T} / \mathrm{T}$ & $\mathrm{G} / \mathrm{G}$ & $\mathrm{C} / \mathrm{C}$ & $\mathrm{G} / \mathrm{A}$ & 0.017 & 0.000 \\
\hline $\mathrm{T} / \mathrm{T}$ & $\mathrm{G} / \mathrm{G}$ & $\mathrm{C} / \mathrm{C}$ & $\mathrm{G} / \mathrm{G}$ & 0.167 & 0.139 \\
\hline $\mathrm{T} / \mathrm{T}$ & $\mathrm{G} / \mathrm{G}$ & $\mathrm{C} / \mathrm{T}$ & $\mathrm{G} / \mathrm{G}$ & 0.017 & 0.000 \\
\hline
\end{tabular}

TGF-B1, transforming growth factor-B1.

${ }^{*} P<0.05, P_{\mathrm{C}}=\mathrm{ns}$.

Italians. The functional relevance of the different distribution of this genotype remains to be clarified.

As a part of the 15th IHWS some innate immune genes such as KIR and MBL2 associated with susceptibility to infections have been assessed as possible biomarkers related to aging. KIR gene polymorphism was studied in two populations - one in the north (Irish) and another in the south (Bulgarians). Comparison of KIR genotype distribution in the Irish cohort shows significantly increased frequencies of KIR2DS3 $(P<0.05$, $\left.P_{\mathrm{c}}=\mathrm{ns}\right)$ and KIR2DL5 in the aged subset compared with the young controls (Table 6), suggesting that these KIR genes may play a role in successful aging in this population. On the other hand, only a trend toward a higher frequency of KIR2DL2 and lower KIR2DL3 and 2DS1 was observed in aged Bulgarians. Further, analysis of KIR haplotype distribution was performed in Bulgarians according to the model of Middleton et al. (21). Increased frequencies of A1B1 [haplotype frequency (HF) elderly $=0.136 ;$ HF controls $=0]$, A1B3 $(\mathrm{HF}$ elderly $=$ 0.136; HF controls $=0.059$ ), and A1B4 (HF elderly $=0.136$; $\mathrm{HF}$ controls $=0.059$ ) and a decreased frequency of A1B10 $(\mathrm{HF}$ elderly $=0.091 ; \mathrm{HF}$ controls $=0.176)$ profiles were found in the elderly group but the differences were not statistically significant. Studies are now emerging supporting the effect of the presence or absence of particular KIR genes on the outcome of certain viral infections (22-28). However, little is known about the role of KIR genetic background in the control of cytomegalovirus (CMV) infection, which is strongly implicated as part of the 'immune risk profile' in longitudinal studies of elderly Swedes (29). It has been shown that a donor KIR profile, containing either KIR2DS2 and 2DS4 or having $\geq 5$ activating KIR genes is predictive for a low risk of CMV reactivation in the recipient after hematopoietic stem cell transplantation (24). In a case study of a child with a novel immunodeficiency syndrome KIR2DL1 expression on all natural-killer (NK) cells was associated with recurrent
Table 6 KIR gene frequencies in elderly and young controls from the Irish population

\begin{tabular}{lccccc}
\hline & \multicolumn{4}{c}{ KIR gene frequency } \\
\cline { 2 - 3 } & \multicolumn{2}{c}{$\begin{array}{c}\text { Young controls } \\
(n=100)\end{array}$} & & \multicolumn{2}{c}{$\begin{array}{c}\text { Elderly individuals } \\
(n=100)\end{array}$} \\
\cline { 2 - 3 } \cline { 5 - 6 } KIR gene & $n$ & $(\%)$ & & $n$ & $(\%)$ \\
\hline 2DL2 & 49 & 49.0 & & 52 & 55.9 \\
2DL3 & 93 & 93.0 & & 82 & 88.2 \\
2DS1 & 36 & 36.0 & & 42 & 45.2 \\
2DS2 & 49 & 49.0 & & 52 & 55.9 \\
2DS3* & 25 & 25.0 & & 38 & 40.9 \\
2DS4 & 94 & 94.0 & & 88 & 94.6 \\
2DS5 & 28 & 28.0 & & 32 & 34.4 \\
3DS1 & 39 & 39.0 & & 42 & 45.2 \\
3DL1 & 94 & 94.0 & & 87 & 93.5 \\
2DL5 & 45 & 45.0 & & 55 & 59.1 \\
2DL4, 3DL2, 3DL3 & 100 & 100 & & 93 & 93 \\
\hline
\end{tabular}

$\mathrm{KIR}$, killer-cell immunoglobulin-like receptors.

$* P<0.05, P_{\mathrm{c}}=\mathrm{ns}$.

CMV infection (25). As aging is associated with chronic, lowgrade inflammatory activity thought to be amplified by persistent infection with CMV, the correlation between KIR and CMV status in the elderly was analyzed (Figure 1). Decreased frequencies of KIR2DS5 $(P>0.05)$ and A1B10 haplotypes $\left(P<0.05, P_{\mathrm{c}}=\mathrm{ns}\right)$ were found in the group with higher $(>20$ $\mathrm{IU} / \mathrm{ml}) \mathrm{CMV}$-specific IgG antibody levels. Taking into consideration that KIR2DS5 is an activating receptor and the A1B10 haplotype is characterized by more inhibitory and less activating KIRs in comparison with the other $\mathrm{AB}$ profiles (except A1B1), different mechanisms leading to the same effects on persistent CMV could be applicable as previously suggested in other viral infections (26-28). Interestingly, the presence of the A1B10 profile in combination with HLA-DR11 and DR16 (alleles contained within longevity-associated HLA haplotypes) was noted in individuals with low-grade CMV seropositivity $(<20 \mathrm{IU} / \mathrm{ml})$. Along these lines, an association between DRB $1 * 1101 / \mathrm{DQB} 1 * 0301$ and HCV clearance has also been reported (22). A possible explanation for this finding could be that epistatic interactions between certain HLA and KIR haplotypes may contribute to the generation of a more effective immune response and suppression of a latent viral infection. As KIRs act in combination with their ligands further efforts to define associations between KIR/HLA ligand combinations and CMV status will greatly enhance our ability to elucidate the role of KIRs in successful aging.

It is well established that MBL serum levels are highly variable and that they are genetically determined by six SNPs. Three independent SNPs: cdn 52 (C/T; Arg/Cys, allele D); cdn 54 (G/A; Gly>Asp, allele B); and cdn 57 (G/A; Gly> Glu, allele $\mathrm{C}$ ) disrupt the collagenous structure of the protein and dramatically reduce serum MBL concentrations (30-32). Any of these mutations (B, C, or D) is referred to as $\mathrm{O}$, while the wild type is referred to as A. In addition to exon one SNPs, 
Inhibitory KIRs

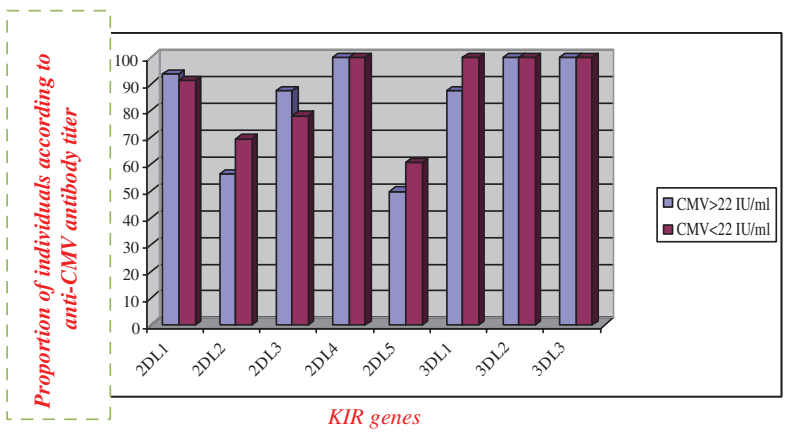

Activatory KIRs

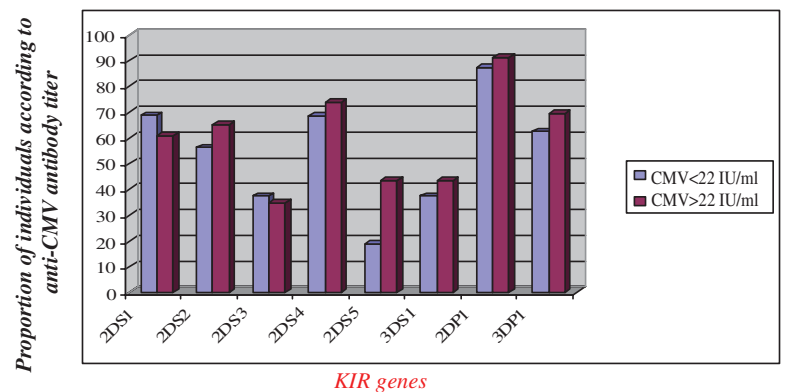

Figure 1 Correlation of killer-cell immunoglobulin-like receptor (KIR) gene distribution and the anti-cytomegalovirus (CMV) antibody titer. Analysis of the distribution of KIR genes showed decreased frequencies of KIR2DS5 ( $P=\mathrm{ns}$ ) in the group with higher (>20 IU/ml) CMV-specific $\lg \mathrm{G}$ antibody levels.

three regulatory variants in the promoter and in the $5^{\prime}$-UTR regions at positions $-619(\mathrm{C} / \mathrm{G}$; allele $\mathrm{L} / \mathrm{H}),-290(\mathrm{G} / \mathrm{C}$; allele $\mathrm{Y} / \mathrm{X})$, and $-66(\mathrm{C} / \mathrm{T}$; allele $\mathrm{P} / \mathrm{Q})$ also influence final serum MBL concentration. Combinations of these six SNPs result in widespread haplotypes determining different serum MBL levels (33, 34): deficiency (haplotypes LYPB, LYQC, and HYPD); low level (haplotype LXPA); intermediate level (haplotype LYPA); and high level (haplotypes HYPA and LYQA). MBL allele and haplotype distribution is quite diverse in different populations and MBL deficiency is one of the most common immune deficiencies, the clinical consequences of which have been extensively studied over the past few years. As a part of the component 'Immunogenetics of Aging' we also sought associations of MBL2 polymorphisms and CMV infections in elderly. Our preliminary results showed that in the elderly, MBL2 haplotypes determining absence of the protein (LYPB, LYQC, and HYPD) were more frequent in those with a CMV antibody titer of $>20 \mathrm{IU} / \mu \mathrm{l}$ compared with those with a titer of $<20 \mathrm{IU} / \mathrm{ml}$ (37\% vs 26\%, p-ns) (Figure 2). Therefore, this might be studied further as a useful additional relevant marker in aging.

In summary, our previous results suggest that longevity is associated with HLA haplotypes shown to be protective for diseases. Additionally, genotypes related to an enhanced anti-inflammatory profile could be positively associated with longevity. Extended genotypes are more informative in aging because of their possible functional significance. Inheritance of extended haplotypes in families with long-lived members allowed us to identify immunogenetic profiles that could be predictive of longevity. Innate immunity genes are associated with susceptibility to infections and might be relevant genetic markers in aging and longevity.

At the end of the 15th IHIW, a consensus was reached on recommendations for future progress. A major challenge in evaluating the large number of genes that are likely to be picked up by the new techniques now available will be to distinguish which of the many differences are involved in the aging process, and which are a consequence of it. It was concluded that additional samples/data from different ethnic groups should be collected and additional, possibly functionally relevant polymorphisms in other genes such as TLR4, CD14, CCR5, and MMP3 should be included. Expression studies of IL and KIR genes would contribute to a more precise assessment of the influence of the genetic background on human longevity.

\section{References}

1. Herskind AM, McGue M, Holm NV, Sørensen TI, Harvald B, Vaupel JW. The heritability of human longevity: a
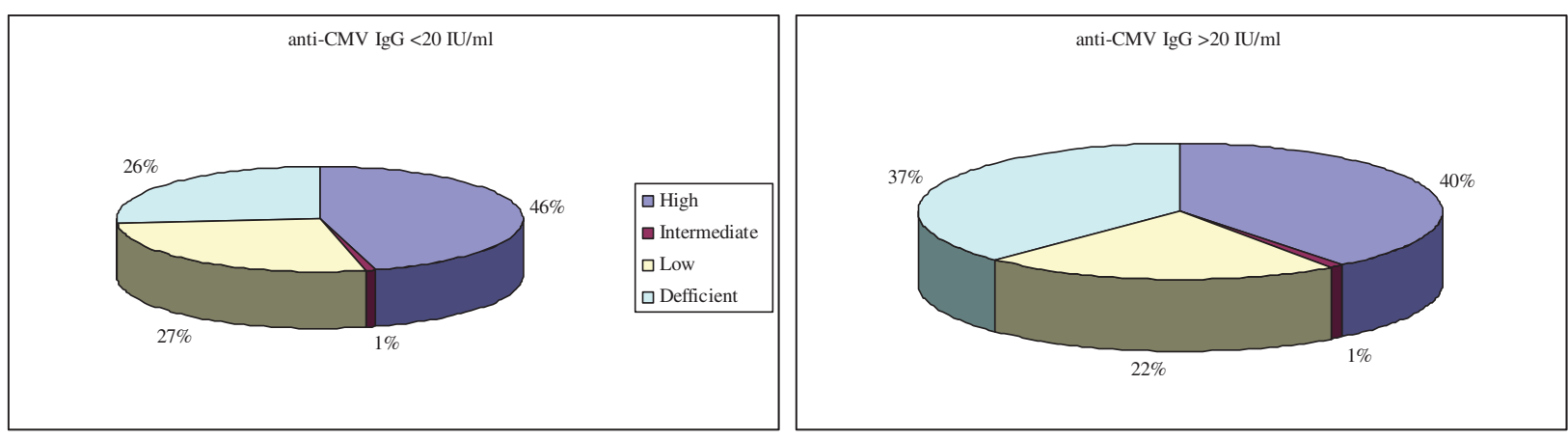

Figure 2 Mannose-binding lectin 2 (MBL2) haplotype distribution and anti-cytomegalovirus (CMV) antibody levels in the elderly: high level of MBL - HYPA, LYQA; intermediate level of MBL2 - LYPA; low level of MBL2 - LXPA; and deficiency of MBL2 - LYPB, LYQC, HYPD. 
population-based study of 2872 Danish twin pairs born 1870-1900. Hum Genet 1996: 97: 319-23.

2. Mitchell BD, Hsueh WC, King TM et al. Heritability of life span in the Old Order Amish. Am J Med Genet 2001: 102: 346-52.

3. Perls TT, Wilmoth J, Levenson R et al. Life-long sustained mortality advantage of siblings of centenarians. Proc Natl Acad Sci U S A 2002: 99: 8442-7.

4. Modica M, Cammarata G, Caruso C. HLA-B8, DR3 phenotype and lymphocyte responses to phytohaemagglutinin. J Immunogenet 1990: 17: 101-7.

5. Naumova E, Pawelec G, Ivanova M et al. 14th International HLA and Immunogenetics Workshop: report on the Immunogenetics of Aging. Tissue Antigens 2007: 69 (Suppl 1): 304-10.

6. Forsey RJ, Thompson JM, Ernerudh J et al. Plasma cytokine profiles in elderly humans. Mech Ageing Dev 2003: 124: 487-93.

7. Ershler WB, Keller ET. Age-associated increased interleukin-6 gene expression, late-life diseases, and frailty. Аnnu Rev Med 2000: 51: 245-70.

8. Bidwell J, Keen L, Gallagher G et al. Cytokine gene polymorphism in human disease: on-line databases, supplement 1. Genes Immun 2001: 2: 61-70.

9. Lio D, Scola L, Crivello A et al. Gender-specific association between $-1082 \mathrm{IL}-10$ promoter polymorphism and longevity. Genes Immun 2002: 3: 30-3.

10. Wang XY, Hurme M, Jylha M, Hervonen A. Lack of association between human longevity and polymorphisms of IL-1 cluster, IL-6, IL-10 and TNF-alpha genes in Finnish nonagenarians. Mech Ageing Dev 2001: 123: 29-38.

11. Ross OA, Curran MD, Meenagh A et al. Study of age-association with cytokine gene polymorphisms in an aged Irish population. Mech Ageing Dev 2003: 124: 199-206.

12. Carrieri G, Marzi E, Olivieri F et al. The G/C915 polymorphism of transforming growth factor betal is associated with human longevity: a study in Italian centenarians. Aging Cell 2004: 3: 443-8.

13. Bonafe M, Olivieri F, Cavallone L et al. A gender-dependent genetic predisposition to produce high levels of IL-6 is detrimental for longevity. Eur J Immunol 2001: 31: 2357-61.

14. Rea IM, Ross OA, Armstrong $M$ et al. Interleukin-6-gene C/G 174 polymorphism in nonagenarian and octogenarian subjects in the BELFAST study. Reciprocal effects on IL-6, soluble IL-6 receptor and for IL-10 in serum and monocyte supernatants.Mech Ageing Dev 2003: 124: 555-61.

15. Bruunsgaard H, Benfield TL, Andersen-Ranberg $\mathrm{K}$ et al. The tumor necrosis factor alpha $-308 \mathrm{G}>\mathrm{A}$ polymorphism is associated with dementia in the oldest old. $J$ Am Geriatr Soc 2004: 52: 1361-6.

16. Lio D, Scola L, Crivello A et al. Allele frequencies of $+874 \mathrm{~T} \rightarrow \mathrm{A}$ single nucleotide polymorphism at the first intron of interferon-gamma gene in a group of Italian centenarians. Exp Gerontol 2002: 37: 315-9.

17. Ligthart GJ, Corberand JX, Fournier C et al. Admission criteria for immunogerontological studies in man: the SENIEUR protocol. Mech Ageing Dev 1984: 28: 47-55.
18. Ivanova M, Ruiqing J, Matsushita M et al. MBL2 single nucleotide polymorphism diversity among four ethnic groups as revealed by a bead-based liquid array profiling. Hum Immunol 2008: 69: 877-84.

19. Shneider S, Rosseli JK, Excoffier L. Arlequin: A Software Environment for the Analysis of Population Genetics Data. Geneva: Genetics and Biometry Lab, 1996.

20. Slatkin M, Excoffier L. Testing for linkage disequilibrium in genotypic data using the Expectation-Maximization algorithm. Heredity 1996: 76: 377-83.

21. Middleton D, Williams F, Halfpenny IA. KIR genes. Transpl Immunol 2005: 14: 135-42.

22. Martin MP, Carrington M. Immunogenetics of viral infections. Curr Opin Immunol 2005: 17: 1-7.

23. Kulkarni S, Martin MP, Carrington M. The Yin and Yang of HLA and KIR in human disease. Semin Immunol 2008: 20: 343-52.

24. Zaia JA, Sun JY, Gallez-Hawkins GM et al. The effect of single and combined activating killer immunoglobulin-like receptor genotypes on cytomegalovirus infection and immunity after hematopoietic cell transplantation. Biol Blood Marrow Transplant 2009: 15: 315-25.

25. Gazit R, Garty BZ, Monselise Y et al. Expression of KIR2DL1 on the entire NK cell population: a possible novel immunodeficiency syndrome. Blood 2004: 103: 1965-66.

26. Khakoo SI, Thio CL, Martin MP et al. HLA and NK cell inhibitory receptor genes in resolving hepatitis $\mathrm{C}$ virus infection. Science 2004: 305: 842-4.

27. Romero V, Azocar J, Zuniga J et al. Interaction of NK inhibitory receptor genes with HLA-C and MHC class II alleles in Hepatitis $\mathrm{C}$ virus infection outcome. Mol Immunol 2008: 45: 2429-36.

28. Thio CL, Thomas DL, Carrington M. Chronic viral hepatitis and the human genome. Hepatology 2000: 31: 819-27.

29. Pawelec G, Derhovanessian E, Larbi A, Strindhall J, Wikby A. Cytomegalovirus and human immunosenescence. Rev Med Virol 2009: 19: 47-56.

30. Lipscombe RJSM, Hill AV, Lau YL, Levinsky RJ, Summerfield JA, Turner MW. High frequencies in African and non-African populations of independent mutations in the mannose binding protein gene. Hum Mol Genet 1992: 1: 709-15.

31. Madsen HOGP, Kurtzhals JA, Lamm LU, Ryder LP, Thiel S, Svejgaard A. A new frequent allele is the missing link in the structural polymorphism of the human mannan-binding protein. Immunogenetics 1994: 40: 37-44.

32. Sumiya MSM, Tabona P, Levinsky RJ, Arai T, Turner MW, Summerfield JA. Molecular basis of opsonic defect in immunodeficient children. Lancet 1991: 337: 1569-70.

33. Madsen HOGP, Thiel S, Kurtzhals JA, Lamm LU, Ryder LP, Svejgaard A. Interplay between promoter and structural gene variants control basal serum level of mannan-binding protein. J Immunol 1995: 155: 3013-20.

34. Madsen HOSM, Hogh B, Svejgaard A, Garred P. Different molecular events result in low protein levels of mannan-binding lectin in populations from southeast Africa and South America. J Immunol 1998: 161: 3169-75. 